had been active in a wide range of public-service appointments, and in 1974 had initiated the much-praised fortnightly programme Scientifically Speaking for what is now BBC Radio 3. Maddox's great ambition, however, was to make Nature more accessible and to reach more readers, and when he returned again as editor in 1980 he devoted his main energies to that end. His eye for raw ability remained: in large part through his encouragement of bright and committed staff, Nature prospered as never before.

If his energy challenged and exhausted (and sometimes provoked) his younger colleagues, and if his motorway driving terrified the older ones, John Maddox's enthusiasm proved contagious and he remained admired and forgiven in exactly the right proportions until his retirement. $\mathrm{He}$ was intolerant of boredom and incapable of boring anyone else. A kind, very clever man, his friendship was treasured, and with pride, by many.

\section{Nicholas Byam Shaw}

Nicholas Byam Shaw joined Macmillan Publishers Ltd in 1964, and was managing director from 1969 to 1990.

\title{
Maddox by his successor
}

It was early 1980 and the news was astonishing. John Maddox was coming back to be, for the second time, the editor of Nature.

To appreciate just how astonishing this was, you have to know about certain negative-sounding facts that some would say shouldn't be part of a tribute. But Maddox saw journalism, and his editorship, as above all being about uncovering truths, however uncomfortable.

At the time the news broke, the editor of Nature, David "Dai” Davies, had just decided to move on after seven years. Then a junior editor in the physical sciences, I was as concerned as the rest of my editorial colleagues about who might take over. As part of a consultative procedure, we'd seen the names on the shortlist, and were underwhelmed. To judge by what happened next, Macmillan's then managing director Nicholas Byam Shaw, whose own tribute to Maddox precedes this one, wasn't that keen on them either.

Dai Davies had had the task of taking over Nature from Maddox in 1973. Maddox had made the journal very much his own fiefdom over a period of seven years, and had left, so rumour had it, under something of a cloud. Indeed, I was told on my own first arrival at Nature in 1979 that one of our principal agendas was to restore the journal's reputation following Maddox's (as it was described) over-involvement, which had resulted in sometimes whimsical decision-making and delays in the handling of scientific papers.

So, a year or so later, you can imagine my surprise, and the consternation (leading to at least one departure) of more senior staff, when Byam Shaw, sweeping aside the shortlist and all consultation, announced that the new editor was to be John Maddox. I'd prefer not to speculate on what Dai Davies's feelings were, although I have no doubt that he handled the transition with decency and professionalism.

So Maddox took over, and Nature proceeded to do what it had done for much of his previous editorship. It thrived.

As I recall from my time as physicalsciences editor (I moved on to launch Physics World in 1988), Maddox did not involve

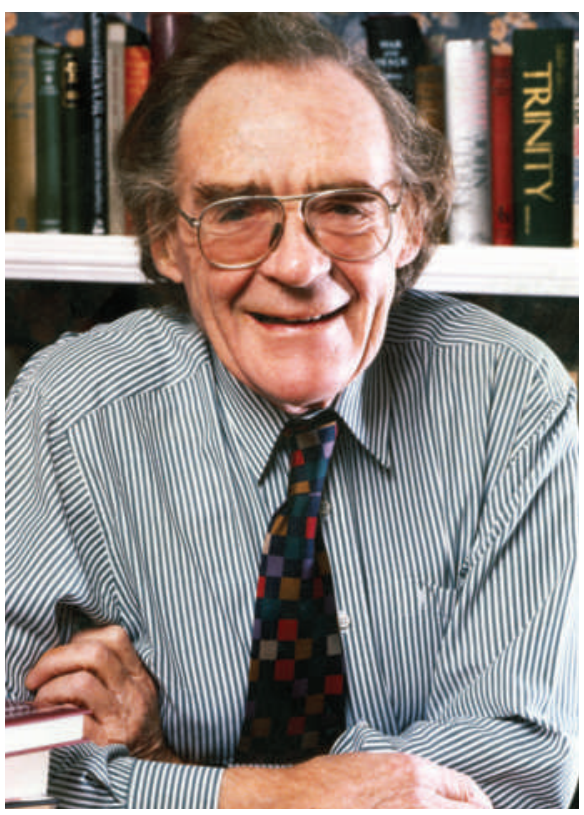

Retired and knighted, 1996.

himself much in decisions over scientific papers. Nevertheless, as he described on his final retirement (see Nature 378, 521-523; 1995), it was he, when he first became Nature's editor in 1966, who had transformed the assessment of such manuscripts from a process based on word-of-mouth recommendations to a system based on peer review. By the time he took over again from Davies, that system was less dependent on the editor and far more dependent on specialist editors in close contact with their respective communities - as it still is.

Despite his original establishment of the peer-review process at Nature, Maddox always had strong reservations about its conservatism. These were perhaps best reflected in his view that the Watson and Crick paper on the structure of DNA wouldn't pass muster under the current system. That paper was published as a result of recommendations by Lawrence Bragg, the head of Watson and Crick's laboratory, and John Randall. (The idea of Nature publishing a paper on the recommendations of the head of the authors' lab is nowadays, of course, sadly but appropriately laughable.)

But, as Maddox's redoubtable and indispensable assistant Mary Sheehan knew only too well - as did some authors who appealed to him to reverse his staff's decisions - committing himself to close involvement with even a few manuscripts was usually a recipe for aeons of delay. Indeed, I fully expect to be told that a pile of stillunanswered appeals has been discovered in the back of his car. On the other hand, he was also delighted occasionally to spot a really important paper and ensure its processing and publication at record-breaking speed.

Although Maddox had learned to delegate the assessment of submitted papers, he worried that his staff were, like referees, too conservative, and also (especially in hot areas of biology), too intent on achieving high impact factors and not ready enough to recognize bold ideas. I suspect there isn't an editor anywhere who doesn't worry about missing great new ideas, and we all have ways of trying to address the issue. Maddox had the willingness and authority very occasionally to ignore or even abandon the peer-review system when he was convinced that it would do nothing but delay publication. He ignored it in publishing the cosmological ideas of Fred Hoyle and colleagues - Hoyle was just the sort of brilliantly unconventional scientist whom Maddox respected most and abandoned it altogether in publishing the first, controversial hominid discoveries made by Richard Leakey at the Olduvai Gorge.

But it was as a journalist that Maddox most made his mark as Nature's editor, in both of his incarnations. The journal's significant increase in international circulation in the 1980s and 1990s during his second stint reflected not only strong marketing but also the impact of his journalistic instincts at play. And I mean 'play', rather than work. Like every Editor of Nature (and many of their colleagues), he worked ridiculous hours, but knew that the secret of survival was, above all, simply to enjoy the work. One of his favourite stated reasons for embarking on a controversial course of action was that it would be 'Fun' - a Maddoxian term received by colleagues with an equal measure of glee and foreboding.

Throughout his editorships, he was fecund in his writing, and brilliantly voracious in his scientific interests. Often more reliant on his 
capacious memory than was advisable for accuracy, his errors of fact were a blemish in his writings, at least in later years. But for me and many other readers, such faults rarely seemed to undermine the stimulating quality at the heart of what he had to say.

There were many controversies - some more resonant than others. One that has left little impact, but that much preoccupied him, sprang from a combination of his loathing of political correctness in environmental issues and his scientific instinct that people were exaggerating the dangers in global change. The latter instinct was at the heart of his attack on Rachel Carson's Silent Spring in his book The Doomsday Syndrome (McGrawHill, 1972). But it was the combination of science and guts, I think, that subsequently led him to campaign against the espousal by Carl Sagan and others of nuclear-winter scenarios, and against the consensus-forming principles of the Intergovernmental Panel on Climate Change.

Several other controversies were, in my view, more interesting and certainly focused the minds of his editorial colleagues. I much regret that he never fulfilled his wish to write a book about three notorious debates in which he played an important part: AIDS and Peter Duesburg, 'cold fusion', and Jacques Benveniste's claim that water can have 'memory'. Although he no doubt relished the controversies as Fun, I am certain that he was intellectually fully committed in his pursuit of them. He truly believed that those casting doubt on links between HIV and AIDS were scientifically pernicious, and campaigned accordingly. He wanted to ensure the scientific integrity of claims and rebuttals of cold fusion, and took trouble to ensure that his decisions to reject one of the original claims and to publish one of the experimental rebuttals were well founded.

And as for Benveniste, the episode will go down in the annals of scientific publishing as one extreme way to handle a report of what seems to be an absurd scientific result that comes from a well-respected laboratory and that the referees cannot fault: publish, and then send in an inquisitional team, including the conjuror James Randi, to investigate. Benveniste's results could not be replicated. A good account of the affair can be found in Philip Ball's book $\mathrm{H}_{2} \mathrm{O}$ : A Biography of Water (Phoenix, 2000). (Phil was working at Nature at the time of the controversy.) People sometimes ask me whether I would have done such a thing. Hindsight is always 20-20, but perhaps I'd have brought in the conjuror before rather than after publication.

Maddox was close to influential people just about everywhere, not least the British establishment - he was a networker par excellence, and made it his business to know at least cabinet ministers and preferably prime ministers. But he never seemed to fit comfortably within these charmed circles in
Britain until after he had retired - if then. This was probably right and proper - his opinionated leading articles usually ensured that he was unpopular with somebody important. Characteristically, sometime in the mid-1980s, he walked out of a meeting of the UK Medical Research Council to which he had been invited. He did so, by his own account, as soon as he realized that he'd been summoned to defend his public criticisms of the body and its then head, James Gowans.

Despite, or perhaps partly because of, such attitudes, but also no doubt as a tribute to his lifetime of achievement as a science journalist and editor, he was awarded a specially created honorary fellowship of the Royal Society and a knighthood, soon after his retirement.

As a result of his controversies, Maddox made enemies, but also attracted people who remember him fondly as an editor willing to champion unusual ideas before everyone else had seen their value. Ultimately, his complete editorial independence was backed by Nicholas Byam Shaw and by the Macmillan family, then Nature's owners, who simply referred all complaints about him directly to him.

Maddox also championed places. He instigated a series of regional supplements, and liked nothing more than to plunge into a place historically, geographically, politically and scientifically — and recount its many aspects in 20 or 30 pages of Maddoxian prose.

Arrogance? Journalistic hubris? Maybe so, yet the results, especially when he was inspired by scientists' resilience in the face of obstacles in, say, India or Russia, were often compelling. But at a cost. As one of my colleagues, production editor Charles Wenz, describes it, a supplement was 'finished' in Maddox's mind when he knew what he wanted to say. The nuts and bolts of putting it together came later, usually after the deadline.

It has been said of the archetypal Great Man (by Nietsche) that "he is colder, harder, less hesitating and without fear of opinion". To me, whether Maddox was a Great Man or not, that seems a fair description. Nietsche also said that such a person "wears a mask: there is a solitude within him that is inaccessible to praise or blame." Maddox was as capable as anyone of openly enjoying people's company or, when necessary, of good poker-like negotiation. He was someone for whom collegiality mattered, but for whom it was ultimately impersonal. He was a good judge of people, often supportive, never (as far as I know) betraying the interests of his staff whereas, in professional contexts, he could be ruthless and always retained a cool-headed detachment. These qualities, combined with his journalistic virtuosities, made him a controversial editor but also a great one. I've deliberately kept this account factual, by and large. Maddox appointed many talented people, some of whom still work for Nature and have good memories of him. He sacked some talented people too, who may have a more negative perspective than I do. But I've not tried to appraise him. I couldn't do it even if it were appropriate for me to try. In that impersonal sense that I have mentioned, I was influenced by his journalistic approach he showed by example rather than tuition what could be done, while respecting his colleagues' capacity for making their own judgements. In various ways, both in the publication and in the Nature offices, things have changed significantly since he left - whether for better or worse is for others to judge. But many of the basic standards and procedures that he established are still in operation.

When, in 1980, I heard that John Maddox was returning to be Nature's editor again, all I knew about him was his radio broadcasts on science, to which I and other young researchers I knew had listened avidly, and the rather questionable aura around his name when it was mentioned in the Nature office at that time. So I had a quiet word with Dai Davies, in full awareness of Dai's rather delicate position, but also knowing his integrity, and asked him to tell me about John. Not being a close acquaintance of John's himself, and no doubt conscious of sensitivities too, he didn't tell me much. But he said one thing that seemed simplistic at the time but which I came to see as profoundly true about John, and which is as fitting an epitaph for Nature's pages as anyone could wish: John loved science.

\section{Philip Campbell}

Philip Campbell succeeded John Maddox as editor of Nature in 1995. 